\title{
The Shreveport Caddo, 1835-1838
}

Jim Tiller

Unknown

Follow this and additional works at: https://scholarworks.sfasu.edu/ita

Part of the American Material Culture Commons, Archaeological Anthropology Commons, Environmental Studies Commons, Other American Studies Commons, Other Arts and Humanities Commons, Other History of Art, Architecture, and Archaeology Commons, and the United States History Commons

Tell us how this article helped you.

This Article is brought to you for free and open access by the Center for Regional Heritage Research at SFA ScholarWorks. It has been accepted for inclusion in Index of Texas Archaeology: Open Access Gray Literature from the Lone Star State by an authorized editor of SFA ScholarWorks. For more information, please contact cdsscholarworks@sfasu.edu. 


\section{The Shreveport Caddo, 1835-1838 \\ Creative Commons License \\ (c) $($ ) $(9)$}

This work is licensed under a Creative Commons Attribution-NonCommercial 4.0 International License 


\title{
THE SHREVEPORT CADDO, 1835-1838
}

\author{
Jim Tiller \\ Professor of Geography \\ Sam Houston State University
}

\begin{abstract}
Period records, such as the reports of Many, Bonnell and Riley, clearly make reference to at least four Caddo villages located between the Red River and the United States-Mexico/Texas boundary in the mid-1830s. In the early 1990s, one of these sites, Timber Hill, was located just to the west of Jim's Bayou in Marion County. In this article I will discuss the location and demise of at least four and possible five additional 1830s-era villages located south of Caddo Lake. In the interest of preserving the sites mentioned, the specific locations of the villages discussed in this article are approximate.
\end{abstract}

Kcywords: Caddo, boundary, Darby, Harrison County, Caddo Lake, 1838 US Surveys, North village, Middle village, Big Spring village

\section{The Boundary}

Reports by Many, Bonnell, and Riley in the period leading up to and immediately after Texas Independence make clear there were at least four Caddo villages found within the bounds of the United States in the area between the Lake Sodo complex and the Sabine River. ${ }^{1}$ Because these men were military officers, it is probably safe to say these villages were all located in Louisiana. It is not likely American army officers would have been reconnoitering Indian villages in Texas.

Of course, prior to 1841 , there was no officially defined boundary between Texas and Louisiana north of the Sabine River. That said, it would not be correct to say that those living in the area did not have some understanding as to the location of the boundary. It appears that between the signing of the Adams-Onis Treaty in 1819 and the completion of the surveys for Northwest Louisiana's Range 17 West in 1838, a recognized boundary did in fact exist, and that this location was known to those in the area. In a September 17, 1830, letter to John W. Eaton, American Secretary of War, Jehiel Brooks, the Red River Caddo Agent, complained of the activities of Peter Bean and his failure to honor the "customary boundary" then in place between the United States and Mexico. According to Brooks, Bean was threatening to permit Cherokees west of the Sabine River under his jurisdiction to cross into Louisiana and destroy the Caddo nation. Brooks also observed that the aforementioned boundary was one that had, by custom, been mutually agreed to until Mexico and the United States "could agree upon and mark out a definite line." ${ }^{2}$ 
The "customary boundary" mentioned by Brooks was almost surely the line that ran north from the intersection of the $32^{\text {nd }}$ parallel and the Sabine River as established by William Darby. In mid-October 1812, Darby, a nineteenth-century geographer and manof-letters, left Natchitoches, Louisiana, and made his way southwest in an effort to locate the elusive intersection of the Sabine River and $32^{\circ} \mathrm{N}$ latitude, ${ }^{3}$ a significant reference point first noted in the Neutral Ground Agreement of $1806 .{ }^{4}$ Darby's work was later used by Philadelphia map maker, John Melish, to produce his famous 1816/1818 map of Louisiana. ${ }^{5}$ The Adams-Onis Treaty of 1819 used Darby's Sabine $/ 32^{\circ} \mathrm{N}$ intersection to define the boundary between Spanish eastern Texas and the United States. ${ }^{6}$

While it is not possible to precisely locate Darby's point of intersection, and therefore his line north to the Red River, a comparison of landmarks present on the Melish map and modern topographic maps (Figure 1) suggests the Line to have been located within a quarter of a mile either side of the line that passed between Section 3 and 4 of Northwest Louisiana's Range 17 West. This line is approximately 3.5 miles west of the modern Texas-Louisiana boundary north of the Sabine River. In contrast, as regards accuracy, the 1838 American surveys placed the western boundary of the United States in this area some 6.5 miles west of the present Texas-Louisiana boundary.

\section{The Villages}

The author in researching the historical geography of eastern Harrison County between 1836 and 1841 spent several hundred hours in the Texas General Land Office (GLO) and State Archives during the spring and summer of 2006 searching for towns, roads, and other historic period cultural features. In the course of that effort, several Caddo villages were located south of Caddo Lake (Figure 2).

According the GLO surveys, the North, Middle, and Big Spring villages are definitely Caddo. The Louisiana village is probably Caddo. The Big Spring and Louisiana villages appear to be the two villages Bonnell visited in the spring of 1836 . He noted two Caddo villages 12 miles apart: the Big Spring and Louisiana villages are approximately 11 miles apart. Based on the lack of any visible water source, and the fact that there is no indication of any period road passing through or near the Boundary village, this "village" is probably an eastward extension of the Middle Village (and thus Caddo) - if not, then there is no indication of the origin of the Boundary village. It will be noted that this village is at the extreme western edge of the $17^{\text {th }}$ Range. American surveyors did not concern themselves with anything not on or within the bounds of that range. A city could have been just west of their location and they would not have made note of it. 


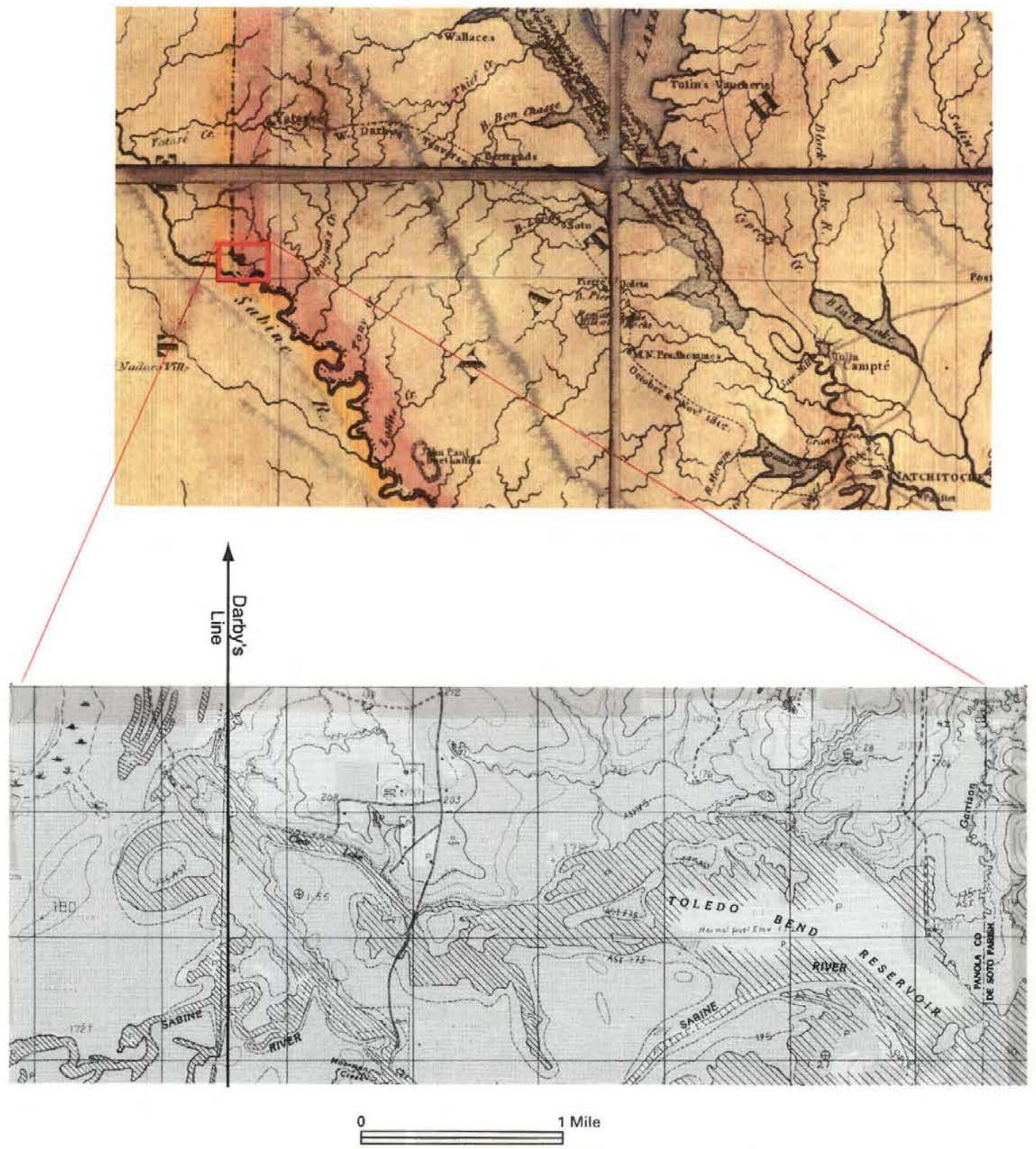

Figure 1. Darby's Intersection. ${ }^{7}$ 


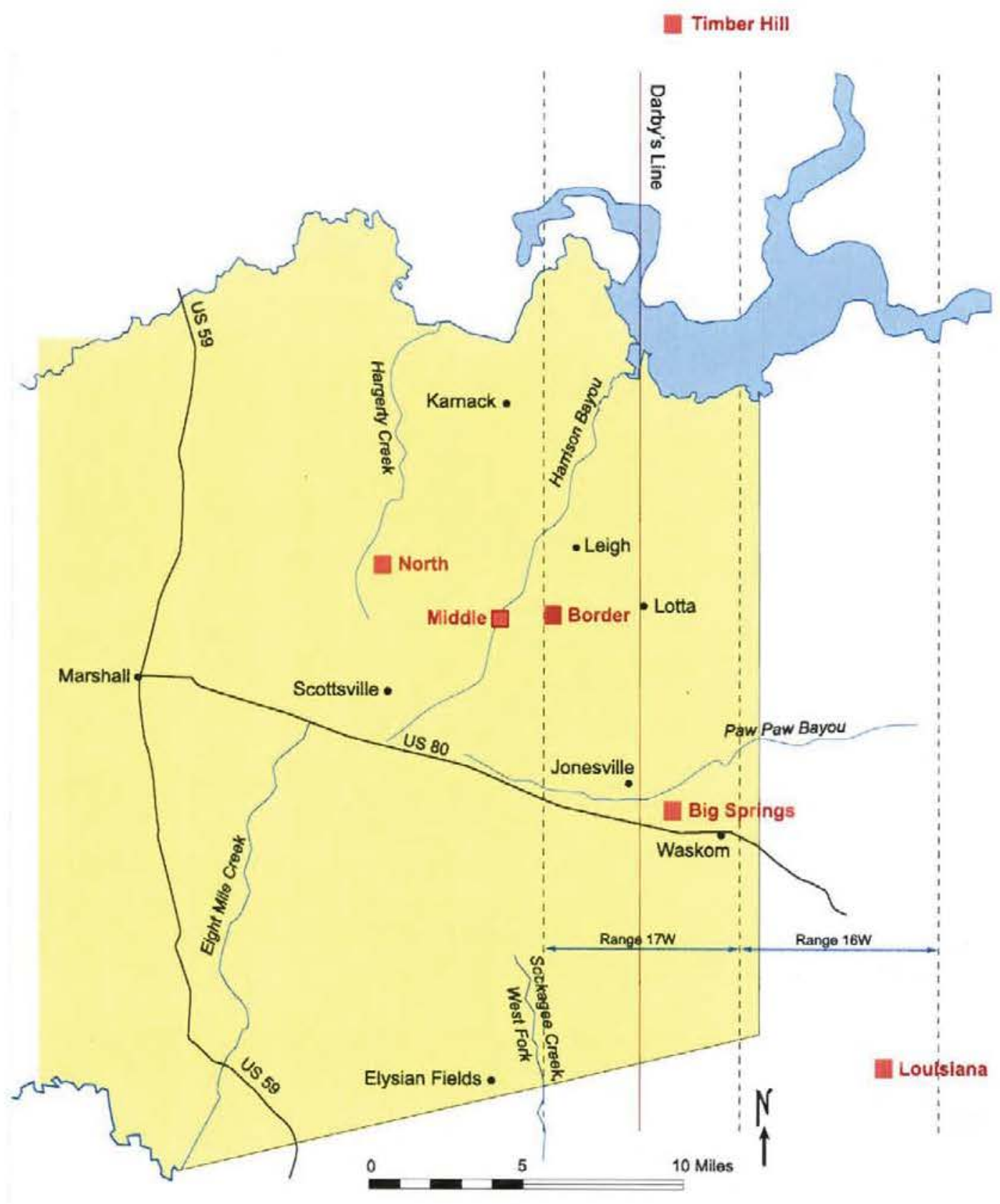

Figure 2. Border Caddo Settlements. 
By the early 1830s, it was clear that the Caddo lands west of the Red River would soon be opened to survey and organized settlement. In 1833, Henry Shreve had cleared the Great Raft to a point just south of modern-day Shreveport. In addition to Shreve, Caddo difficulties included a general shortage of game, hostile tribes to the west, the increasing presence of Anglo-American settlers from both the north and south along the Red River, and Mexican surveyors from Texas. By September 1834, the United States had closed the Caddo Agency just south of Shreveport and with that event came the loss of the gunsmith and blacksmith employed to serve the Caddo, as well as a horse-powered mill used by them to grind corn.

In July 1835 , the Caddo sold their land to the United States for $\$ 80,000$. They received $\$ 30,000$ upon the sale, $\$ 10,000$ a year for the next five years, and, importantly for our purposes, they agreed to leave the confines of the United States within one year.

\section{Where Did The Caddo Go?}

We know that upon the sale of their lands, some of the Caddo left almost immediately for Texas; settling on the upper Neches (the Treaty between the Republic and the Cherokee and Associated Bands of February 23, 1836, makes reference to the Caddo of the Nechez). ${ }^{8}$ The balance of the tribe (sometimes referred to in later documents as the Caddoes from Shreveport or the "Shreveport Indians") ${ }^{9}$ remained in the border area. Apparently some of these Caddo, while continuing to live along the border, were engaged in raids on the interior of Texas.

It is clear from Major Riley's report that at least four villages were still to be found within the border area of Louisiana as late as the spring/summer of 1836 . I suspect those noted by Riley were the Middle, Big Spring, and Louisiana villages south of Caddo Lake, and the Timber Hill village north of the Lake. The North Caddo Village was probably not established until late 1836. We know American General Edmund P. Gaines, because of his concerns over general Indian unrest in Texas in the wake of the Revolution, refused to allow these Caddo to remove to Texas prior to July 1836.

\section{When Were These Villages Established?}

Excluding Timber Hill, 1 found nothing definitive in my research that would indicate the age of any of these villages. The roots of the North Caddo village probably lie in a January 9,1837, letter sent by several Caddo chiefs to the American Secretary of War. Most of the letter is concerned with the naming by the Caddo of a new Agent (Green) to accept their 1837 treaty installment of $\$ 10,000$. Near the end of the letter, they note the following:

We have established our villages near the head of Lake Sodo which we believe to be without the boundary of the United States, but on running the 
line between Mexico and the U.S. should it be found to be within the jurisdiction of the latter, we will instantly remove further to the west. Hope you will inform the President of our great wish to have this line run out as we can make no permanent settlement until this is done. ${ }^{10}$

This statement is interesting for a number of reasons. First note that the Caddo are indicating they have recently established ... villages (plural):

- they were located near the head of Lake Sodo;

- they were outside, but likely relatively near the supposed boundary (Darby's Line); and

- they were not permanent (again, the implication is that they are not old).

Based on the 1835 Treaty requirements, one would think it safe to assume that the North and Middle villages probably contained the balance of the Caddo (excluding Timber Hill) who had not previously moved to the Neches River and points west. But such may not be the case. The Middle village may have existed prior to the sale of Caddo lands - and thus prior to the January 9, 1837 letter noted above. Field notes from two surveys in the general area between the North and Middle villages, and both sharing a common survey line, indicate an "old field" 1300 varas southwest along the common line. Combining the survey sketch maps and other period maps, it is reasonably clear that this "old field" (if indeed it was Indian and not Anglo-American) belonged to the Middle and not the North Caddo village. Based upon village representations on sketch maps from two other surveys in the same general area drawn by the same surveyor some four months apart in the spring of 1838, it seems clear that the Middle Caddo village was considerably larger than the North village.

Now, one could conclude that the relative size of the two villages sketched was the result of the "smaller" North village lying outside the surveyors' primary effort. On the other hand it would not be unreasonable to assume that the Middle village, as compared to the North village, was in fact the more substantial settlement. In addition to there being a reference in a period survey to the North village being a "small Indian village," the Middle Caddo village was a cross-roads settlement with roads leading in three directions. And again, it may be that the Boundary village is just an eastward extension of the Middle Caddo village.

If the Middle village is an old village, then based on the use of the plural villages in the January 9, 1837 letter, there may be at least one other mid-1830s Caddo village yet to be located.

The author strongly suspects that the Big Spring village is the same settlement referred to in the Handbook of Texas as Biff Springs, the site of Old Elysian Fields. ${ }^{11}$ Unreferenced sources indicate that in 1816-1817, Edward Smith, one of the early settlers in southeastern Harrison County, passed through a Caddo Indian village named Biff 
Springs located on the site that would later become known as Elysian Fields. Attracted by the beauty of the area, he later returned to make his home on Sockagee Creek and the old Shreveport to Grand Bluff road. Some preliminary archeological work has been done in the Old Town area, but as yet nothing definitive has emerged as regards Caddo settlement. Based on some considerable personal knowledge of the area (the Tiller family initially settled the area just west of Old Town in 1836 and continue to this day to be landowners in the area), the author suspects that somewhere along the line Big (or Bigg) Spring got translated to Biff Spring. If such were the case, and Smith's foray into the area did in fact transpire in the time period supposed, then the Big Spring village probably dates to the early 1800 s.

\section{When Were the Villages Abandoned?}

Timber Hill aside, to even begin to sort out the dates these villages were abandoned, one must keep in mind at least three points:

(1) that in late 1836 when some Caddo villages (again plural) were apparently moved westward, aside from Darby's Line, there was no hard and fast boundary between the United States and Texas;

(2) that the United States was actively engaged in surveying the lands to the west of Shreveport in the 1837-1838 period; and

(3) the contents of the 1837 Caddo letter to the American Secretary of War.

The Louisiana village clearly lay within R16W which the United States had contracted for survey on January $1,1837 .{ }^{12}$ While the Caddo could not have known this at the time they penned their January 9 letter, it appears the Louisiana village was one of those abandoned in the fall/winter of 1836. In March 1837, U.S. surveyors at the site of the village cryptically noted: "A deserted village."

The contract for surveying Township 17N, Range 17W, the site of Big Spring village, was let on October $1 .{ }^{13}$

Probably by summer 1837, the Caddo would have realized that the survey of R17W would result in an additional 6 miles being surveyed to the west. At this point it would have been clear to them that Big Spring village would have to be abandoned - and possibly the Boundary village as well (assuming it was an independent village).

The timing of the abandonment of Big Spring village can be relatively precisely determined. We know Shelby County/Harrison District surveyor John S. "Rip" Ford actually camped out in the immediate vicinity of this village in February/March 1838 . He noted in his memoirs regarding this visit that: "This point was inhabited by Caddo Indians." He also observed that "Within a radius of twenty miles there were three or four Indian villages." 14 
When U.S. surveyors moved through the area just two months after Ford's visit, in late April 1838, they noted the site of Big Spring village as: "an old Indian Village (now in ruins)." ${ }^{15}$ Because there were many Indian problems in this general area in the spring and summer of 1838 , it appears the word ruins in this instance seems to imply destruction.

Those occupying the Big Spring village probably moved west to join the Caddo occupying the North and Middle Caddo (and possibly the Timber Hill) villages, the U.S surveyors having found the site of the Boundary village deserted in April 1838. The Caddo likely remained in the North and Middle villages until the end of September 1838 when, at the request of Caddo Agent Charles Sewell, and in order to receive their annual $\$ 10,000$ installment, 156 Caddo men, women and children (which possibly represented the total population of the North and Middle Caddo villages at the time) came to Shreveport. What is known, is that after their two brushes with armed Texans in the fall of $1838,{ }^{16}$ the Shreveport Caddo apparently never returned as a tribe to their Harrison County villages.

\section{Footnotes}

${ }^{1}$ United States Congress. House of Representatives. House Document $351.25^{\text {th }}$ Congress, $2^{\text {nd }}$ Session. pp. 815-816.

${ }^{2}$ National Archives and Records Administration. Letters Received by the Office of Indian Affairs, Caddo Agency 1824-1842. National Archives Microfilm Publications M-234, Roll 31 (Brooks to Eaton, September 17, 1830).

${ }^{3}$ Garrett, Julia Kathryn. Dr. John Sibley and the Louisiana Frontier, 1803-1814 (Continued). Southwestern Historical Quarterly, Vol. XLIX, No. 3. (January 1946), pp. $417-418$.

${ }^{4}$ Haggard, Villasana. The Neutral Ground Between Louisiana and Texas, 1806-1821. The Louisiana Historical Quarterly, Vol. 28, No. 4 (October 1945), pp. 1001-1128.

${ }^{5}$ Darby, William and John Melish. A Map of the State of Louisiana with Part Of The Mississippi Terrilory, from Actual Survey By Wm. Darby. Philadelphia, John Melish. 1: $633,600.1816$.

${ }^{6}$ Treaty of Amity, Settlement, and Limits (Adams-Onis). Treaties and Other International Acts of the United States of America. Edited By Hunter Miller. Volume 3. Washington D.C., U.S. Government Printing Office, 1933, p. 5.

${ }^{7}$ Darby, William and John Melish. A Map of the State of Louisiana with Part OfThe Mississippi Territory, from Actual Survey By Wm. Darby. Philadelphia, John Melish. 1: 633,600. 1816; United States Geological Survey. Maps. Galloway, Texas and adjacent 
quads. 1:24,000, 7.5 Minute Series. Washington, D. C.: United States Government Printing Office, 1983.

${ }^{8}$ Everett, Dianna. The Texas Cherokee: A People Between Two Fires 1819-1840.

Norman: University of Oklahoma Press, 1990. p. 71.

${ }^{9}$ National Archives and Records Administration. Letters Received by the Office of Indian Affairs, Caddo Agency 1824-1842. National Archives Microfilm Publications M-234, Roll 31 (Armstrong to Crawford, March 5, 1841).

${ }^{10}$ National Archives and Records Administration. Letters Received by the Office of Indian Affairs, Caddo Agency 1824-1842. National Archives Microfilm Publications M234, Roll 31 (Brooks to Cass, January 9, 1837).

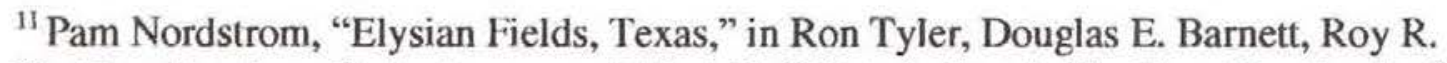
Barkley, Penelope C. Anderson, and Mark F. Odintz (editors), The New Handbook of Texas (6 vols.; Austin: Texas State Historical Association, 1996), Volume I, p. 859.

${ }^{12}$ United States Department of the Interior, Bureau of Land Management, Plat map and field notes for T16N, R16W. Surveyed March 1837.

${ }^{13}$ United States Department of the Interior, Bureau of Land Management, Plat map for T17N, R17W. Surveyed April 27, 1838.

${ }^{14}$ Ford, John Salmon (edited by Stephen B. Oates), Rip Ford's Texas. Austin: University of Texas Press, 1963. pp. 25-26.

${ }^{15}$ United States Department of the Interior, Bureau of Land Management, Plat map and field notes for T17N, R17W. Surveyed April 27,1838.

${ }^{16}$ National Archives and Records Administration. Letters Received by the Office of Indian Affairs, Caddo Agency 1824-1842. National Archives Microfilm Publications M234, Roll 31 (Jenkins affidavit, January 1, 1839). 